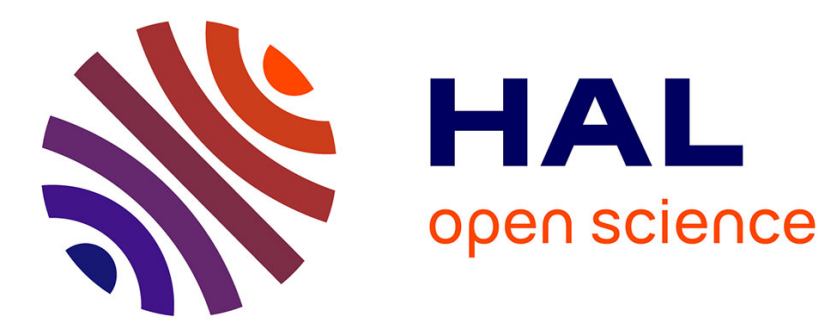

\title{
Geochemical characteristics of basalts related to incipient oceanization: The example from the Alpine-Tethys OCTs
}

Méderic Amann, Marc Ulrich, Gianreto Manatschal, Eric Pelt, Marie-eva Epin, Julia Autin, Daniel Sauter

\section{To cite this version:}

Méderic Amann, Marc Ulrich, Gianreto Manatschal, Eric Pelt, Marie-eva Epin, et al.. Geochemical characteristics of basalts related to incipient oceanization: The example from the Alpine-Tethys OCTs. Terra Nova, 2019, 32 (1), pp.75-88. 10.1111/ter.12438 . insu-02456734

\section{HAL Id: insu-02456734 https://hal-insu.archives-ouvertes.fr/insu-02456734}

Submitted on 30 Nov 2020

HAL is a multi-disciplinary open access archive for the deposit and dissemination of scientific research documents, whether they are published or not. The documents may come from teaching and research institutions in France or abroad, or from public or private research centers.
L'archive ouverte pluridisciplinaire HAL, est destinée au dépôt et à la diffusion de documents scientifiques de niveau recherche, publiés ou non, émanant des établissements d'enseignement et de recherche français ou étrangers, des laboratoires publics ou privés. 
${ }^{1}$ Institut de Physique du Globe de Strasbourg (IPGS)-EOST, CNRS-UMR 7516, Université de Strasbourg, 5, rue

\section{Abstract}

Basalts exposed in the Platta and Tasna nappes (SE Switzerland) derive from the Alpine-Tethys OceanContinent Transitions (OCT) and overlie SubContinental Lithospheric Mantle (SCLM). We show that the trace element signatures of these basalts differ from Mid-Ocean Ridge Basalts (MORB). Two types of basalts occur in the OCT: a type-1 showing a "garnet signature" that can be modeled by the partial melting of the SCLM in the spinel stability field and a type- 2 characterized by an enrichment in incompatible elements that can be explained by the mixing between garnet-pyroxenite-derived melts and the melting of either a depleted MORB mantle or a refertilized SCLM. Based on geological and geochemical observations we propose that the basalts from the Alpine-Tethys OCTs result from a poly-phase magmatic system that carry an inherited SCLM signature. These basalts should therefore be referred to as OCT-basalts rather than as MOR-basalts. basalt. 


\section{Introduction}

The geochemical composition of mid-ocean ridge basalts (MORB) is due to the partial melting of a

depleted mantle source (DMM). One remaining key question is whether basalts from magma-poor oceancontinent transitions (OCTs) are formed by similar melting processes as MORB or if they reflect more complex mantle processes associated with lithospheric thinning of a sub-continental lithospheric mantle (SCLM). Basaltic samples derived from present-day magma-poor OCTs are rare and limited to few samples drilled at the Iberia-Newfoundland (Chazot et al., 2005; Cornen et al., 1999; Robertson, 2007), the South China Sea (Sun et al., 2016) or the Diamantine OCT (Beslier et al., 2004; Chatin et al., 1998). In contrast, Alpine-Apennine ophiolites expose remnants of the OCTs of the ancient magma-poor Jurassic Alpine Tethys, which provide information not only on the basalts but also on the underlying mantle (Picazo et al., 2016). Previous studies on basalts derived from the fossil Alpine-Tethys OCT show that they are characterized by a wide range of trace element compositions, from depleted basalts (Bill et al., 2000; Desmurs et al., 2002; Durand-Delga et al., 1997; Kramer et al., 2003; Montanini et al., 2008; Piccardo, 2008; Saccani et al., 2008) to enriched basalts (Frisch et al., 1994; Renna et al., 2018; Steinmann and Stille, 1999; Vannucci et al., 1993) leading to various interpretations concerning the parental sources of these basalts. Over the last decade, a considerable data set has been acquired on the mantle rocks from Alpine-Tethys OCTs (Müntener et al., 2010; Picazo et al., 2016; Piccardo, 2016; Rampone et al., 2008). This new knowledge, combined with the geological observations, enable to better discriminate between the various interpretations and to understand the processes involved in magma-production at deeper parts of the lithosphere during mantle exhumation and lithospheric breakup.

In this paper, we present a compilation of Alpine-Tethys basalt chemistry including new data from the Platta and Tasna nappes (SE Switzerland, Fig. 1a). The lack of a major Alpine metamorphic overprint, the excellent exposure and the understanding of the mantle evolution prior and during breakup of these two nappes allowed to propose a tectono-magmatic model that may explain the peculiar geochemistry of the basalts of the Alpine-Tethys OCT. 


\section{Geological setting}

\subsection{Remnants of OCTs in the Alps}

The Tasna and Platta nappes represent well preserved remnants of a fossil OCT of the ancient European and Adriatic conjugate rifted margins (Manatschal et al., 2006; Manatschal and Nievergelt, 1997) that were related to the opening of the Jurassic Liguro-Piemonte/Alpine Tethys ocean (Fig. 1b). This ocean probably was a narrow basin $(<600 \mathrm{~km}$-wide) that developed as a result of an ultra-slow spreading activity (Marroni and Pandolfi, 2007; Li et al., 2013). The Tasna nappe is part of the northeastern European OCT preserving a wedge of continental crust that is laterally replaced by exhumed subcontinental mantle and grades into proto-oceanic crust with first magmatic additions (Manatschal et al., 2006). The Penninic Platta nappe is subdivided into two Alpine tectonic units, the Upper and the Lower Platta units (Supplementary material S1). The Upper Platta nappe is bounded at its top by the Lower Austroalpine Err nappe (part of the Adria distal continental margin) and overlies Middle and Lower Penninic nappes (remnant of the European distal margin; Manatschal and Nievergelt, 1997). Both the Platta and Tasna nappes, as well as the majority of Alpine-Apennine ophiolites, consist of highly serpentinized peridotites intruded by large gabbroic bodies and overlain locally by massive basaltic lava flows, continent-derived extensional allochthons and post-rift sediments (supplementary material S2, Desmurs, 2002; Desmurs et al., 2001; Peters et al., 2008).

\subsection{Nature of the exhumed mantle}

Two main types of mantle have been distinguished all around the Alpine-Tethys and more particularly in the Tasna and Platta nappes (Fig. 2a, Picazo et al., 2016). The first type identified in the Tasna and Upper Platta units consists of spinel lherzolites containing abundant garnet-bearing pyroxenites (Desmurs, 2002; Müntener et al., 2010; Peters et al., 2008). Major and trace element compositions in clinopyroxene demonstrate the fertile character of these mantle rocks (Picazo et al., 2016). This mantle, referred to as the inherited subcontinental mantle, is similar to the mantle exhumed in the proximal parts of the present-day Iberia-Newfoundland OCTs (Müntener and Manatschal, 2006). 
The second type of mantle composing the lower Platta unit consists of spinel Iherzolites with minor

harzburgites and dunites and shows only few occurrences of pyroxenites (Desmurs, 2002; Müntener et al., 2010, 2004; Peters et al., 2008). This peridotite is pervasively impregnated by ascending tholeiitic melts (Müntener et al., 2010, 2004) that pre-date the Middle Jurassic mantle exhumation (Piccardo, 2016; Rampone et al., 1995). This mantle type has also been described from the distal part of the Iberia margin (Müntener and Manatschal, 2006) and is considered to be the refertilized part of exhumed subcontinental mantle (see type 2 mantle in Picazo et al. 2016).

\section{Basalts from the Platta and Tasna OCTs}

\subsection{Petrology of extrusive magmatic rocks and basaltic intrusions}

Extrusive basaltic rocks exposed in the Platta and Tasna nappes (supplementary material S3) occur as hyaloclastites, pillow breccias, pillow lavas and massive lava flows that can reach up to $300 \mathrm{~m}$ thickness (Fig. 2a-b). Basalts lie on exhumed mantle and are covered by Upper Jurassic to Lower Cretaceous marine sediments (Fig. 2c). Basalts exhibit intersertal to porphyric textures and contain plagioclase phenocrysts embedded in a fine-grained matrix of plagioclase, chlorite, epidote, pumpellyite and calcite (Fig. 2d). Hyaloclastite breccias consist of fragments of lava flows, which probably derive from the dislocation of former volcanic deposits. A Jurassic age (167-161 Ma) is based on the dating of radiolarian cherts that are either interlayered or overlie the basalts (Bill et al., 2001) and U-Pb on gabbros that are genetically linked to the basalts (Schaltegger et al., 2002).

A younger magmatic event consisting of sills of 10 to $20 \mathrm{~m}$ thickness (Fig. 2e) has been found in the Platta nappe. These sills intrude limestones and shales of Lower Cretaceous age (Peters et al., 2008), representing the youngest pre-Alpine magmatic event identified so far in the Alpine OCT. The sills are characterized by finegrained textures at the rims and coarse-grained at the center. They are composed of plagioclase, chlorite, pumpellyite and epidote (Fig. 2f). 
A comprehensive description of analytical methods for chemical analysis are given in supplementary material S4. Major element content of our samples is similar to those of other basalts from the Platta nappe (Desmurs et al., 2002; Frisch et al., 1994). Considering both their mineralogical and geochemical compositions, they range between tholeiite and alkali basalt in nature $\left(\mathrm{SiO}_{2}: 45-50\right.$ wt.\%; $\mathrm{Al}_{2} \mathrm{O}_{3}: 15-19$ wt.\%; $\mathrm{Na}_{2} \mathrm{O}+\mathrm{K}_{2} \mathrm{O}<5$ wt.\%) and display relatively low Mg\# $(<0.65)$ showing that they represent differentiated melts rather than primitive liquids (Table 1).

On the basis of trace element compositions, two different types of Jurassic basalts can be distinguished (Fig. 3). Type-1 is depleted in incompatible elements, shows a positive $\mathrm{Zr}$ anomaly, a low $(\mathrm{La} / \mathrm{Sm})_{\mathrm{N}}$ and is comparable to "normal" MORB. Type- 1 shows a large fractionation of HREE over MREE, $(\mathrm{Sm} / \mathrm{Yb})_{\mathrm{N}}=0.82-1.76$, and a widespread $\mathrm{Nb} /$ La ratio (0.55 to 3.25). Samples characterized by medium to high HREE over MREE and a low $\mathrm{Nb} / \mathrm{La}$ ratio are volumetrically predominant in the Platta-Tasna nappes as well as in the entire Alpine Tethys margins (Fig. 5). The type- 2 is enriched in incompatible elements (>10 times PUM concentrations) and high field strength elements (HFSE, Nb, Ta, Zr, Hf; Fig. 3). Type-2 basalts have high $(\mathrm{La} / \mathrm{Sm})_{\mathrm{N}}>1.3$ and high $(\mathrm{Sm} / \mathrm{Yb})_{\mathrm{N}}>1.5$ ratios, and are similar to present-day enriched MORB (E-MORB; Gale et al., 2013). Although of a different apparent age, trace element patterns of Cretaceous sills (type-3) are similar to those of Jurassic EMORB. This geochemical diversity is not restricted to Platta and Tasna basalts but have been described in several ophiolites of the Alpine-Tethys domain (e.g. Bill et al., 2000 and Supplementary material S6).

\section{Origin of OCT-basalts}

Basalts from this study are representative of basalts from the Alpine-Tethys (Fig. 4). The Cr vs. Y diagram shows that all these basalts result from $5 \%$ to $15 \%$ partial melting followed by various degrees of fractional crystallization (Fig. 4). However, their variable trace element patterns (Fig. 3), illustrate that the Platta-Tasna basalts (types-1, 2 and 3) as well as other basalts from the Alpine Tethys may not derived from the melting of a depleted mantle source but rather may reflect the melting of another mantle source. 
Type-1 basalts depletion in LREE makes them to a first order comparable to N-MORB (Erreur ! Source

du renvoi introuvable.a). However, most of these basalts as well as most of the Alpine-Tethys basalts substantially differ from present-day MORB by lower $\mathrm{Nb} / \mathrm{La}$ ratios and higher $(\mathrm{Sm} / \mathrm{Yb})_{\mathrm{N}}$ ratios (Erreur ! Source du renvoi introuvable. and supplementary material $\mathrm{S} 5)$. High $(\mathrm{Sm} / \mathrm{Yb})_{\mathrm{N}}$ ratios are classically used as a proxy to identify the presence of a garnet-bearing component in the MORB source (Hellebrand et al., 2002; Montanini et al., 2008; Saccani, 2015; Sobolev et al., 2007; Stracke et al., 1999). The melting of a DMM-like source in the spinel stability field hardly produces basalts with $(\mathrm{Sm} / \mathrm{Yb})_{N}>1.2$, even at low degrees of melting, while most of the Alpine basalts display $(\mathrm{Sm} / \mathrm{Yb})_{N}>1.2$ (see supplementary material $\left.\mathrm{S} 5\right)$. Such high $(\mathrm{Sm} / \mathrm{Yb})_{N}$ ratios are easily simulated by melting a depleted mantle source in the garnet stability. However, both modeling approaches fail to reproduce the low $\mathrm{Nb} / \mathrm{La}$ ratio that characterize most of the Alpine basalts (Erreur ! Source du renvoi introuvable.b). Since $\mathrm{Nb}$ is more incompatible than $\mathrm{La}\left(\mathrm{D}_{\mathrm{Nb}}<\mathrm{D}_{\mathrm{La}}\right), \mathrm{Nb} / \mathrm{La}$ ratios tend to decrease in both the residual mantle and the extracted melts with increasing melt degree. Thus, basalts with $\mathrm{Nb} / \mathrm{La}<0.7$ must be derived from the melting of a mantle source more refractory than the asthenospheric DMM. (mantle type 1a from Picazo et al., 2016) or too depleted (mantle type 1b from Picazo et al., 2016). Similarly, the oceanic mantle (type 3 from Picazo et al., 2016) is too depleted and occurs too oceanward from the location where basalts erupted. However, the refertilized mantle section (mantle type 2; Picazo et al., 2016) may be a plausible source. The geochemical composition of this refertilized mantle is calculated following the modelling approach of Müntener et al. (2010). The starting mantle composition is the PUM, which has undergone $4 \%$ partial melting in the garnet (4\%) stability field, followed by $4 \%$ in the spinel stability field. This residual mantle is then refertilized by ascending melts (up to $12 \%$ in volume) deriving from the melting of an asthenospheric depleted source (DMM) in the spinel stability field. Fig. 5a, b shows that the melting of such a refertilized source is able to produce melts similar to type-1 basalts with low $\mathrm{Nb} / \mathrm{La}$ and high $(\mathrm{Sm} / \mathrm{Yb})_{\mathrm{N}}$. The calculated 
made on Alpine basalts (Desmurs et al., 2002). This model is very similar to the one proposed previously by Meyzen et al., (2003) to explain the peculiar REE signature of some MORB from the northern magma-poor section of the ultraslow-spreading Southwest Indian Ridge. More importantly, this model is consistent with geological observations made by previous studies (Müntener et al., 2010; Picazo et al. 2016).

\subsection{The formation of "E-MORB"-like basalts (types-2 and 3)}

Aside from type-1 basalts, a few percent of extrusive basalts can be ascribed as enriched-basalts (EMORB, types-2 and 3). Additional occurrences of E-MORBs have been reported previously in other fossil OCT in the Alps (External Ligurides and Corsica; Montanini et al., 2008; Renna et al., 2018; Saccani et al., 2008). The enriched nature of these basalts was attributed to the simultaneous melting of the Jurassic ascending asthenosphere (i.e. the DMM) and garnet-pyroxenites. This hypothesis was tested by applying a similar modeling approach to that of Montanini et al., (2008): variable amounts of garnet-pyroxenite derived melts were mixed with (i) aggregated melts of a depleted spinel peridotite source (red mixing lines in Erreur ! Source du renvoi introuvable.c, d) and (ii) type-1 basalts extracted from the refertilized SCLM (blue mixing lines in Erreur ! Source du renvoi introuvable.c, d). Three different partial melting degrees are considered for the formation of depleted melts $(F=0.05,0.1$ and 0.15$)$, while a high partial melting degree of 0.25 is considered for the pyroxenite melt (Montanini et al., 2008). Other modeling features (partition coefficients, pyroxenite source composition, etc.) are given in Erreur ! Source du renvoi introuvable. caption. Results highlight that EMORB melts may derive from the mixing between $80-90 \%$ of depleted MORB and $10-20 \%$ partial melts of garnet-pyroxenite, these results being in good agreement with previous calculations of Sobolev et al., (2007) and Montanini et al., (2008).

\subsection{Geodynamic constraints and conclusions}

Ophiolites from the Alpine-Tethys domain have provided strong evidence for processes of interaction between inherited SCLM and the ascending asthenosphere (Bodinier et al., 1991; Montanini et al., 2008; Müntener et al., 2004; Müntener and Piccardo, 2003; Piccardo et al., 2004b, 2007; Tribuzio, 2004), which is 
different from basalts formed at steady state, mature MORs. Almost all extrusive basalts from the Alpine-

Tethys OCT overlie an exhumed, refertilized SCLM (Picazo et al., 2016). Only a few overlie the inherited SCLM in Central Alps (Upper Platta, Malenco, Totalp, Picazo et al., 2016). We therefore suggest here that the specific geochemistry of basalts from the Alpine-Tethys OCT is related to their emplacement over the exhumed, refertilized SCLM. The upward melt infiltration coming from the partial melting of the DMM in the garnet stability field creates the widespread refertilized SCLM (type 2 mantle of Picazo et al. 2016). This melting episode is enhanced by a near-adiabatic decompression regime (McKenzie and Bickle, 1988) during the very first stages of lithospheric thinning and asthenospheric uplift (Piccardo et al., 2004a, Fig. 5a). Melt percolation occurred during lithospheric/crustal thinning and was controlled by tectonic processes and the thermal structure of the extending lithosphere, both of which are not well constrained. Kaczmarek and Müntener (2010) proposed, using the example of the Lanzo shear zone, that percolation occurred in the footwall of a major extensional shear zone that acted as a permeability barrier. The thermal advection related to both asthenospheric upwelling and melt percolation is likely able to increase the thermal gradient in order to reach the solidus of the refertilized SCLM at shallower depths in the spinel stability field (Piccardo et al., 2004a, 2004b). Integrating this inherited history of the SCLM may explain the peculiar geochemical signature characterizing most of basalts from the Alpine-Tethys OCTs that were erupted on exhumed SCLM in the distal part of the hyperextended margin (i.e. type-1 basalts, Fig. 5b). In contrast, the enriched basalts may correspond to low degree melts of the DMM with small amounts of garnet-pyroxenite, both before and after the onset of seafloor spreading (Fig. 5b-c). This study supports the idea that basalts erupting in the Alpine-Tethys OCT have long-lived, poly-phase and variable mantle sources. The peculiar trace element geochemistry of basalts and the well-established geodynamic setting of OCT in the Alps with complex mantle inheritance enable to explain the differences between OCT and MOR basalts. Therefore, basalts formed along OCTs should be referred to as OCT-basalts rather than MOR-basalts. 


\section{Acknowledgements}

191

192

We greatly thank Thibault Wiedemann, Nicolas Mattioni, Jean Zielinski and René Boutin for their help during laboratory works. We also thank John Moine for the realization of thin sections. This work is a part of M. Amann Ph.D thesis and has benefited of the financial support provided by the French Ministry of Research and INSU-CNRS through the SYSTER program. None of the authors of the above manuscript has declared any conflict of interest.

\section{References}

Anders, E., Grevesse, N., 1989. Abundances of the elements: Meteoritic and solar. Geochim. Cosmochim. Acta, 53, 197-214. doi.org/10.1016/0016-7037(89)90286-X

Beccaluva, L., Ohnenstetter, D., Ohnenstetter, M., Venturelli, G., 1977. The trace element geochemistry of Corsican ophiolites. Contrib. Mineral. Petrol., 64, 11-31.

Beslier, M.-O., Royer, J.-Y., Girardeau, J., Hill, P.J., Boeuf, E., Buchanan, C., Chatin, F., Jacovetti, G., Moreau, A., Munschy, M., 2004. Une large transition continent-océan en pied de marge sud-ouest australienne: premiers résultats de la campagne MARGAU/MD110. Bull. Soc. Geol. Française, 175, 629-641.

Bill, M., Nägler, T.F., Masson, H., 2000. Major, minor, trace element, Sm-Nd and Sr isotope compositions of mafic rocks from the earliest oceanic crust of the Alpine Tethys. Schweizerische Mineralogische und Petrographische Mitteilungen, 80-2, 131-145.

Bill, M., O’Dogherty, L., Guex, J., Baumgartner, P.O., Masson, H., 2001. Radiolarite ages in AlpineMediterranean ophiolites: Constraints on the oceanic spreading and the Tethys-Atlantic connection. Geol. Soc. Am. Bull., 113, 129-143. 
Bodinier, J., Guiraud, M., Dupuy, C., Dostal, J., 1986. Geochemistry of basic dikes in the Lanzo massif

212 (Western Alps): petrogenetic and geodynamic implications. Tectonophysics, 128, 77-95.

Bodinier, J.-L., Menzies, M.A., Thirlwall, M.F., 1991. Continental to oceanic mantle transition-REE and Sr-Nd isotopic geochemistry of the Lanzo Iherzolite massif. J. Petrol., 2, 191-210.

Chalot-Prat, F., Ganne, J., Lombard, A., 2003. No significant element transfer from the oceanic plate to the mantle wedge during subduction and exhumation of the Tethys lithosphere (Western Alps). Lithos, 69, 69103.

Chatin, F., Robert, U., Montigny, R., Whitechurch, H., 1998. La zone Diamantine (océan Indien oriental), témoin de la séparation entre l'Australie et l'Antarctique: arguments pétrologiques et géochimiques. Comptes Rendus Académie des Sciences, Earth Planet. Sci., 326, 839-845.

Chauvel, C., Bureau, S., Poggi, C., 2011. Comprehensive Chemical and Isotopic Analyses of Basalt and Sediment Reference Materials. Geostand. Geoanalytical Res., 35, 125-143. doi.org/10.1111/j.1751908X.2010.00086.x.

Chazot, G., Charpentier, S., Kornprobst, J., Vannucci, R., Luais, B., 2005. Lithospheric Mantle Evolution during Continental Break-Up: The West Iberia Non-Volcanic Passive Margin. J. Petrol., 46, 2527-2568. doi.org/10.1093/petrology/egi064.

Cornen, G., Girardeau, J., Monnier, C., 1999. Basalts, underplated gabbros and pyroxenites record the rifting process of the West Iberian margin. Mineral. Petrol., 67, 111-142.

Desmurs, L., 2002. Mantle evolution and magmatism in an evolving ocean-continent transition: The Platta nappe, eastern Switzerland. Diss., Naturwissenschaften, ETH Zürich, 14429, 2002.

Desmurs, L., Manatschal, G., Bernoulli, D., 2001. The Steinmann trinity revisited: mantle exhumation and magmatism along an ocean-continent transition: the Platta nappe, eastern Switzerland. Geol. Soc. Lond. Spec. Publ., 187, 235-266. 
Desmurs, L., Müntener, O., Manatschal, G., 2002. Onset of magmatic accretion within a magma-poor rifted margin: a case study from the Platta ocean-continent transition, eastern Switzerland. Contrib. Mineral. Petrol., 144, 365-382. doi.org/10.1007/s00410-002-0403-4

Durand-Delga, M., Peybernès, B., Rossi, P., 1997. Arguments en faveur de la position, au Jurassique, des ophiolites de Balagne (Haute-Corse, France) au voisinage de la marge continentale europeenne. Académie Sci., 325, 973-981.

Dürr, S., Ring, U., Frisch, W., 1993. Geochemistry and geodynamic significance of North Penninic ophiolites from the Central Alps. Schweiz. Mineral. Petrogr. Mitteilungen, 73, 407-419.

Ferrara, G., Innocenti, F., Ricci, C.A., Serri, G., 1976. Ocean-floor affinity of basalts from north Apennine ophiolites: geochemical evidence. Chem. Geol., 17, 101-111.

Frisch, W., Ring, U., Dürr, S., Borchert, S., Biehler, D., 1994. The Arosa Zone and Platta Nappe ophiolites (Eastern Swiss Alps): geochemical characteristics and their meaning for the evolution of the Penninic Ocean. Jahrb Beol BA, 137, 19-23.

Gale, A., Dalton, C.A., Langmuir, C.H., Su, Y., Schilling, J.-G., 2013. The mean composition of ocean ridge basalts: MEAN MORB. Geochem. Geophys. Geosystems, 14, 489-518. doi.org/10.1029/2012GC004334 Hart, S.R., Dunn, T., 1993. Experimental cpx/melt partitioning of 24 trace elements. Contrib. Mineral. Petrol., $113,1-8$.

Hellebrand, E., Snow, J.E., Hoppe, P., Hofmann, A.W., 2002. Garnet-field melting and late-stage refertilization in 'residual' abyssal peridotites from the Central Indian Ridge. J. Petrol., 43, 2305-2338.

Herzberg, C., 2006. Petrology and thermal structure of the Hawaiian plume from Mauna Kea volcano. Nature, 444, 605.

Hirschmann, M.M., Stolper, E.M., 1996. A possible role for garnet pyroxenite in the origin of the "garnet signature" in MORB. Contrib. Mineral. Petrol., 124, 185-208. 
Ionov, D.A., Bodinier, J., Mukasa, S.B., Zanetti, A., 2002. Mechanisms and sources of mantle metasomatism: major and trace element compositions of peridotite xenoliths from Spitsbergen in the context of numerical modelling. J. Petrol., 43, 2219-2259.

Jochum, K.P., Brueckner, S.M., Nohl, U., Stoll, B., Weis, U., 2008. Geostandards and Geoanalytical Research bibliographic review 2007. Geostand. Geoanalytical Res., 32, 509-514.

Johnson, K., Dick, H.J., Shimizu, N., 1990. Melting in the oceanic upper mantle: an ion microprobe study of diopsides in abyssal peridotites. J. Geophys. Res. Solid Earth, 95, 2661-2678.

Johnson, K.T.M., 1998. Experimental determination of partition coefficients for rare earth and high-fieldstrength elements between clinopyroxene, garnet, and basaltic melt at high pressures. Contrib. Mineral. Petrol., 133, 60-68. doi:10.1007/s004100050437

Kogiso, T., Tatsumi, Y., Nakano, S., 1997. Trace element transport during dehydration processes in the subducted oceanic crust: 1 . Experiments and implications for the origin of ocean island basalts. Earth Planet. Sci. Lett., 148, 193-205.

Kramer, J., Abart, R., Müntener, O., Schmid, S.M., Stern, W.B., 2003. Geochemistry of metabasalts from ophiolitic and adjacent distal continental margin units: Evidence from the Monte Rosa region (Swiss and Italian Alps). Swiss Bull. Mineral. Petrol., 83, 217-240.

Lewis, A.D., Smewing, J.D., 1980. The Montgenevre ophiolite (Hautes Alpes, France): Meta-morphism and trace-element geochemistry of the volcanic sequence. Chem. Geol., 28, 291-306.

Li, X.-H., Faure, M., Lin, W., and Manatschal, G., 2013. New isotopic constraints on age and magma genesis of an embryonic oceanic crust: The Chenaillet Ophiolite in the Western Alps. Lithos, 160-161, 283-291, doi.org/10.1016/j.lithos.2012.12.016

Liberi, F., Morten, L., Piluso, E., 2006. Geodynamic significance of ophiolites within the Calabrian Arc. Isl. Arc, $15,26-43$. 
Manatschal, G., Engström, A., Desmurs, L., Schaltegger, U., Cosca, M., Müntener, O., Bernoulli, D., 2006.

What is the tectono-metamorphic evolution of continental break-up: The example of the Tasna OceanContinent Transition. J. Struct. Geol., 28, 1849-1869. doi.org/10.1016/j.jsg.2006.07.014

Manatschal, G., Müntener, O., 2009. A type sequence across an ancient magma-poor ocean-continent transition: the example of the western Alpine Tethys ophiolites. Tectonophysics, 473, 4-19. doi.org/10.1016/j.tecto.2008.07.021

Manatschal, G., Nievergelt, P., 1997. A continent-ocean transition recorded in the Err and Platta nappes (Eastern Switzerland). Eclogae Geol. Helvetiae, 90, 3-28.

Marroni, M., Molli, G., Montanini, A., Tribuzio, R., 1998. The association of continental crust rocks with ophiolites in the Northern Apennines (Italy): implications for the continent-ocean transition in the Western Tethys. Tectonophysics, 292, 43-66.

Marroni, M., Pandolfi, L., 2007. The architecture of an incipient oceanic basin: a tentative reconstruction of the Jurassic Liguria-Piemonte basin along the Northern Apennines-Alpine Corsica transect. Int. J. Earth Sci., 96, 1059-1078. doi.org/10.1007/s00531-006-0163-x

Mazzeo, F.C., De Vita, P., Aulinas, M., Arienzo, I., Cirillo, G., lovine, R.S., Sparice, D., 2016. New constraints on the origin of the ophiolitic rocks within sin-orogenic turbiditic sequences at Cilento region (southern Italy). Geol. Acta Int. Earth Sci. J., 14(3), 299-314.

McDonough, W.F., Sun, S.-S., 1995. The composition of the Earth. Chem. Geol., 120, 223-253.

McKenzie, D., Bickle, M. J. 1988. The volume and composition of melt generated by extension of the lithosphere. .J. Petrol. 29, 625-679.

Meyzen, C.M., Toplis, M.J., Humler, E., Ludden, J.N., Mével, C., 2003. A discontinuity in mantle composition beneath the southwest Indian ridge. Nature, 421, 731-733. doi.org/10.1038/nature01424 
Montanini, A., Tribuzio, R., Thirlwall, M., 2012. Garnet clinopyroxenite layers from the mantle sequences of the Northern Apennine ophiolites (Italy): Evidence for recycling of crustal material. Earth Planet. Sci. Lett., 351, 171-181. doi.org/10.1016/j.epsl.2012.07.033

Montanini, A., Tribuzio, R., Vernia, L., 2008. Petrogenesis of basalts and gabbros from an ancient continent?ocean transition (External Liguride ophiolites, Northern Italy). Lithos, 101, 453-479. doi.org/10.1016/j.lithos.2007.09.007

Mugnier, J.-L., Cannic, S., Lapierre, H., 2008. The tholeiites of the Valaisan domain (Versoyen, western Alps): a Carboniferous magma emplaced in a small oceanic basin. Bull. Société Géologique Fr., 179, 357-368.

Müntener, O., Manatschal, G., 2006. High degrees of melt extraction recorded by spinel harzburgite of the Newfoundland margin: The role of inheritance and consequences for the evolution of the southern North Atlantic. Earth Planet. Sci. Lett., 252, 437-452. doi.org/10.1016/j.epsl.2006.10.009

Müntener, O., Manatschal, G., Desmurs, L., Pettke, T., 2010. Plagioclase Peridotites in Ocean-Continent Transitions: Refertilized Mantle Domains Generated by Melt Stagnation in the Shallow Mantle Lithosphere. J. Petrol., 51, 255-294. doi.org/10.1093/petrology/egp087

Müntener, O., Pettke, T., Desmurs, L., Meier, M., Schaltegger, U., 2004. Refertilization of mantle peridotite in embryonic ocean basins: trace element and $\mathrm{Nd}$ isotopic evidence and implications for crust-mantle relationships. Earth Planet. Sci. Lett., 221, 293-308. doi.org/10.1016/S0012-821X(04)00073-1

Müntener, O., Piccardo, G.B., 2003. Melt migration in ophiolitic peridotites: the message from AlpineApennine peridotites and implications for embryonic ocean basins. Spec. Publ. Geol. Soc. Lond., 218, 69-90.

Ottonello, G., Ernst, W.G., Joron, J.L., 1984. Rare earth and 3d transition element geochemistry of peridotitic rocks: I. Peridotites from the Western Alps. J. Petrol., 25, 343-372. 
Padoa, E., Saccani, E., Durand-Delga, M., 2001. Structural and geochemical data on the Rio Magno Unit: Evidence for a new 'Apenninic' ophiolitic unit in Alpine Corsica and its geodynamic implications. Terra Nova, 13, 135-142.

Peters, T., Dietrich, V.J., Office fédéral de la topographie, 2008. Geologischer Atlas der Schweiz Blätt 1256 Bivio.

Picazo, S., Müntener, O., Manatschal, G., Bauville, A., Karner, G., Johnson, C., 2016. Mapping the nature of mantle domains in Western and Central Europe based on clinopyroxene and spinel chemistry: Evidence for mantle modification during an extensional cycle. Lithos, 266-267, 233-263.

doi.org/10.1016/j.lithos.2016.08.029

Piccardo, G.B., 2016. Evolution of the lithospheric mantle during passive rifting: Inferences from the AlpineApennine orogenic peridotites. Gondwana Res., 39, 230-249. doi.org/10.1016/j.gr.2016.03.001

Piccardo, G.B., 2008. The Jurassic Ligurian Tethys, a fossil ultraslow spreading ocean: the mantle perspective. Geol. Soc. Lond. Spec. Publ., 293, 11-34. doi.org/10.1144/SP293.2

Piccardo, G.B., Müntener, O., Zanetti, A., 2004a. Alpine-Apennine ophiolitic peridotites: new concepts on their composition and evolution. Ofioliti, 29, 63-74.

Piccardo, G.B., Müntener, O., Zanetti, A., Pettke, T., 2004b. Ophiolitic peridotites of the Alpine-Apennine system: mantle processes and geodynamic relevance. Int. Geol. Rev., 46, 1119-1159.

Piccardo, G.B., Padovano, M., Guarnieri, L., 2014. The Ligurian Tethys: Mantle processes and geodynamics. Earth-Sci. Rev., 138, 409-434. doi.org/10.1016/j.earscirev.2014.07.002

Piccardo, G.B., Zanetti, A., Müntener, O., 2007. Melt/peridotite interaction in the Southern Lanzo peridotite: Field, textural and geochemical evidence. Lithos, 94, 181-209. doi.org/10.1016/j.lithos.2006.07.002 Pognante, U., Rösli, U., Toscani, L., 1985. Petrology of ultramafic and mafic rocks from the Lanzo peridotite body (Western Alps). Lithos, 18, 201-214. 
Rampone, E., Hofmann, A., Piccardo, G., Vannucci, R., Bottazzi, P., Ottolini, L., 1995. Petrology, mineral and isotope geochemistry of the External Liguride peridotites (Northern Apennines, Italy). J. Petrol., 36, 81-105.

Rampone, E., Hofmann, A.W., 2012. A global overview of isotopic heterogeneities in the oceanic mantle.

Lithos, 148, 247-261. doi.org/10.1016/j.lithos.2012.06.018

Rampone, E., Hofmann, A.W., Raczek, I., 1998. Isotopic contrasts within the Internal Liguride ophiolite (N.

Rampone, E., Piccardo, G.B., Hofmann, A.W., 2008. Multi-stage melt-rock interaction in the Mt. Maggiore

(Corsica, France) ophiolitic peridotites: microstructural and geochemical evidence. Contrib. Mineral. Petrol.,

$156,453-475$.

Renna, M.R., Tribuzio, R., Sanfilippo, A., Thirlwall, M., 2018. Role of melting process and melt-rock reaction in the formation of Jurassic MORB-type basalts (Alpine ophiolites). Contrib. Mineral. Petrol., 173, 31.

Robertson, A., 2007. Evidence of continental breakup from the Newfoundland rifted margin (Ocean Drilling

Program Leg 210): Lower Cretaceous seafloor formed by exhumation of subcontinental mantle lithosphere, and the transition to seafloor spreading. Presented at the Proceedings of the Ocean Drilling Program, Scientific Results, pp 1-69.

Rudnick, R.L., Barth, M., Horn, I., McDonough, W.F., 2000. Rutile-Bearing Refractory Eclogites: Missing Link Transition Zone (OCTZ) Lithosphere and Their Geochemistry, Mantle Sources and Melt Evolution Patterns. Episodes, 38. doi.org/10.18814/epiiugs/2015/v38i4/82418 basaltic and metabasaltic rocks. Ofioliti, 33, 207. 
Schaltegger, U., Desmurs, L., Manatschal, G., Müntener, O., Meier, M., Frank, M., Bernoulli, D., 2002. The transition from rifting to sea-floor spreading within a magma-poor rifted margin: field and isotopic constraints. Terra Nova, 14, 156-162.

Sobolev, A.V., Hofmann, A.W., Kuzmin, D.V., Yaxley, G.M., Arndt, N.T., Chung, S.-L., Danyushevsky, L.V., Elliott, T., Frey, F.A., Garcia, M.O., others, 2007. The amount of recycled crust in sources of mantle-derived melts. Science, 316, 412-417.

Steinmann, M., Stille, P., 1999. Geochemical evidence for the nature of the crust beneath the eastern North Penninic basin of the Mesozoic Tethys ocean. Geol. Rundsch., 87, 633-643. doi.org/10.1007/s005310050236

Stracke, A., Salters, V.J., Sims, K.W., 1999. Assessing the presence of garnet-pyroxenite in the mantle sources of basalts through combined hafnium-neodymium-thorium isotope systematics. Geochem. Geophys. Geosystems, 1, 12

Sun, Z., Stock, J., Jian, Z., McIntosh, K., Alvarez-Zarikian, C., Klaus, A., 2016. Expedition 367/368 scientific prospectus: South China Sea rifted margin. Int. Ocean Discov. Program.

Tribuzio, R., 2004. Origin of the Gabbro-Peridotite Association from the Northern Apennine Ophiolites (Italy). J. Petrol., 45, 1109-1124. doi.org/10.1093/petrology/egh006

Vannucci, R., Rampone, E., Piccardo, G.B., Ottolini, L., Bottazzi, P., 1993. Ophiolitic magmatism in the Ligurian Tethys: an ion microprobe study of basaltic clinopyroxenes. Contrib. Mineral. Petrol., 115, 123-137.

Venturelli, G., Capedri, S., Thorpe, R., Potts, P., 1979. Rare-earth and other element distribution in some ophiolitic metabasalts of Corsica, Western Mediterranean. Chem. Geol., 24, 339-353.

Venturelli, G., Thorpe, R.S., Potts, P.J., 1981. Rare earth and trace element characteristics of ophiolitic metabasalts from the Alpine-Apennine belt. Earth Planet. Sci. Lett., 53, 109-123.

Workman, R.K., Hart, S.R., 2005. Major and trace element composition of the depleted MORB mantle (DMM). Earth Planet. Sci. Lett., 231, 53-72. 


\section{List of figures and tables}

Fig. 1: (a) Location of major ophiolite massifs in the Alps-Apennine-Corsica (redrawn after Rampone and Hofmann, (2012); Schaltegger et al., (2002). [1]: Tertiary basins; [2]: European Units; [3]: Penninic Units; [4]:

Ophiolitic Units; [5]: Adriatic Units. (b) Schematic paleogeographic reconstruction of the Alpine-Tethys during the Late Jurassic (redrawn after Picazo et al., 2016). The reconstruction is based on structural (Manatschal and Müntener, 2009) as well as mantle geochemical (Picazo et al., 2016; Rampone and Hofmann, 2012) considerations. Ophiolite with $\left({ }^{*}\right)$ highlight ambiguous paleo-location. $\mathrm{CE}$ : Cecina Valley, $\mathrm{CH}$ : Chenaillet, EL:

Malenco, MM: Monte Maggiore, MV: Mont-Viso, UP: Upper Platta, TA: Tasna, TO: Totalp, ZS: Zermatt-Saas. Br: Briançonnais, Sa: Sardinia.

Fig. 2: Macroscopic field and microscopic observations of basalts. (a) Panoramic view of the Err-Platta OceanContinent Transition zone illustrating the position of the inherited and refertilized (infiltrated) subcontinental mantle. UP: Upper Platta; LP: Lower Platta; SCLM: subcontinental lithospheric mantle. (b) Platta outcrop with gabbro body and refertilized mantle, overlain by basalt flows and radiolarian chert. Note that the topographic surface is controlled by both Alpine thrusts and detachment faults. (c) Radiolarian chert sealing a basalt flow (inverse serie). (d) Photomicrograph of Jurassic extrusive basalt showing plagioclase intersertal texture with occurrence of little epidote. (e) Early Cretaceous basaltic sill intruding post-rift sediments. (f) Photomicrograph of Cretaceous basaltic sill showing subhedral granular albitite (doleritic texture). Ep: epidote, PI: plagioclase. $\mathrm{Mg} /(\mathrm{Mg}+\mathrm{Fe})$ (calculated in molar proportions). 
416

417

418

419

420

421

422

423

424

425

426

427

428

429

430

431

432

433

434

435

436

437

Fig. 3: Whole-rock incompatible trace element (normalized to the primitive mantle, PM, McDonough and Sun, 1995) and rare-earth element compositions (normalized to C1 chondrite, Anders and Grevesse, 1989) of basalts from the Platta-Tasna nappes. (a) Type-1 depleted Jurassic extrusive basalts, (b) Type-2 enriched Jurassic extrusive basalts, (c) Type-3 Cretaceous basaltic sills. Dashed black lines N-MORB and E-MORB are from Gale et al., (2013) and other basalts from Platta are from Desmurs et al., (2002).

Fig. 4: $\mathrm{Cr}(\mathrm{ppm})$ versus Y (ppm) of whole-rock Platta-Tasna basalts. The partial melting trend starts from the mean DMM (Workman and Hart, 2005). The arrows indicate the calculated trends of the liquids for fractional crystallization of clinopyroxene + plagioclase $(c p x+p l g)$ assemblages starting from the relatively primitive basaltic sample 13-04 (residual liquid fraction F up to 0.5 ). Mineral mass fractions are $0.2 c p x+0.8 p l g$. Partition coefficients sources for $\mathrm{Y}$ and $\mathrm{Cr}$ are from lonov et al., (2002) and from Hart and Dunn, (1993) respectively. Note that the starting mantle composition does not dramatically change the partial melting models nor the crystal fractionation trends. 1 : Gale et al., 2013, 2 : Other Platta basalts are from Desmurs et al., (2002) and Frisch et al., (1994). Alpine-Apennine basalts (little blue circles) are the overall Alpine-Tethys domain. Internal Ligurides (Ferrara et al., 1976; Ottonello et al., 1984; Rampone et al., 1998; Venturelli et al., 1981), External Ligurides (Marroni et al., 1998; Montanini et al., 2008; Vannucci et al., 1993; Venturelli et al., 1981), Corsica (Beccaluva et al., 1977; Durand-Delga et al., 1997; Padoa et al., 2001; Renna et al., 2018; Saccani et al., 2008; Venturelli et al., 1981, 1979), Western Alps (Bodinier et al., 1986; Chalot-Prat et al., 2003; Lewis and Smewing, 1980; Pognante et al., 1985), Central Alps (Desmurs et al., 2002; Frisch et al., 1994), Tuscany (Ferrara et al., 1976; Mazzeo et al., 2016), Calabre (Liberi et al., 2006) and inferred Valais domain (Bill et al., 2000; Dürr et al., 1993; Kramer et al., 2003; Mugnier et al., 2008; Steinmann and Stille, 1999). 
Fig. 5: (a) Nb/La vs. La showing the compositions of Alpine basalts. The modelling consists of the calculation of $\mathrm{Nb} /$ La ratio of aggregated non-modal fractional liquids that derive from the partial melting of the refertilized SCLM. The chemistry of the refertilized mantle source is calculated following the study of Müntener et al. (2010) : a fertile peridotite (primitive upper mantle, PUM; McDonough and Sun, 1995) experienced 4\% partial melting in the garnet stability field (A) followed by $4 \%$ of additional melting in the spinel stability field (B). The residue is refertilized by adding a $4 \%$ fractional melt derived from a spinel DMM source ( $1 \%$ increment, C). A volume of $1 \%, 3 \%, 6 \%, 9 \%$ and a maximum of $12 \%$ of melts stored in the peridotite is considered (Müntener et al., 2010). The red curves correspond to melts extracted from the calculated refertilized mantle in the spinel stability field at $\mathrm{F}$ up to $20 \%$. Partition coefficients are from Johnson et al., (1998), starting mineralogy and modes are from Johnson et al., (1990). (b) ( $\mathrm{Sm} / \mathrm{Yb}) \mathrm{N}$ vs. $\mathrm{YbN}$ of alpine basalts. Red curves are calculated in the same way as in Fig. 5a. (c) Nb/La vs. La of E-MORB alpine basalts, assuming that they derive from the mixing of aggregated non-modal fractional melts $(F=5,10,15 \%)$ from a spinel DMM source (in red) or a refertilized SCLM (8\% refertilization, in blue) with garnet pyroxenite derived melts ( $F=25 \%$; Montanini et al., 2008). The garnet pyroxenite source derives from high degrees of batch melting ( $F=40 \%$; Montanini et al., 2012) of a recycled oceanic crust (i.e. an eclogite; Sobolev et al., 2007). The eclogite composition ( $C_{\text {eclogite }}$ ) is calculated assuming that eclogite corresponds to basaltic, N-MORB type crust $\left(\mathrm{C}_{\mathrm{N}-\mathrm{MORB}}\right)$ that experienced element mobility during subduction prior being recycled into the mantle: $C_{\text {eclogite }}=C_{N-M O R B}-$ retention factors where retention factors $=$ 1 - mobility coefficients (Kogiso et al., 1997). The calculated eclogite has a high $\mathrm{Nb} /$ La ratio ( 2 , not shown here), consistent with values calculated by Rudnick et al., (2000). Gt-pyroxenite mineralogy: 60\% cpx, 30\% opx, 10\% gt (Hirschmann and Stolper, 1996); melting modes: $\mathrm{cpx}=\mathrm{gt}=50 \%$. Eclogite mineralogy: $50 \% \mathrm{gt}, 50 \% \mathrm{cpx}$. Numbers in italic represent the proportion of mantle derived melts in the mixing. (d) $(\mathrm{Sm} / \mathrm{Yb})_{N} \mathrm{vs}$. $Y b_{N}$ of alpine basalts. Red and blue curves are calculated in the same way as in Fig. $5 \mathrm{c}$. N-star: N-MORB average $\pm 2 \sigma$ (grey area); Present-day MORBs and N-MORB average are from Gale et al. (2013).

Fig. 5 : Schematic representation of the geodynamic model leading to the OCT-basalts. (a) Melt percolation. Near adiabatic upwelling of the asthenosphere (DMM) during this early rifting stage. Onset of asthenosphere 
partial melting in the garnet stability field (pink circles), and initial percolation of melts towards the subcontinental mantle (light brown area) during the stretching of the lithosphere. Porous-flow melt percolation induces (i) the refertilization of Permian (?) depleted SCLM, (ii) the formation of plagioclasebearing peridotite at shallower levels, and (iii) the formation of a weakened mantle wedge for the lithospheric breakup (Piccardo, 2016). The distal subcontinental mantle is melt-impregnated (up to 12\%) and refertilized. Major crustal/lithospheric thinning is followed by mantle exhumation and onset of sea-floor exposure of the melt-modified peridotites. (b) Creation of OCT-basalts. Thermal advection (Piccardo et al., 2014) enhanced by porous-flow melt percolation moves the solidus upwards allowing the melting of the refertilized subcontinental mantle in the spinel stability field (light blue circles) forming the type-1 basalts (light blue pipes and volcanoes). Mixing of melts from the partial melting of the DMM (dark blue circles) and garnet-pyroxenite (black dashes, orange circles) creates type-2 basalts (red pipes and volcanoes). (c) Formation of type-3 off-axis basalts (yellow volcanoes) by the same process as type- 2 . The mixing between the two sources is located at the two edges of the upwelling asthenosphere and is probably related to thermal readjustments. Active spreading ridge followed by MOR-basalt formation caused by the partial melting of the DMM under spinel (shallow) stability field.

\section{Supplementary material}

Supplementary material S1: (a) Location of the Platta and the Tasna nappes in the Alpine realm. (b) Tectonic units and paleogeographic domains close to Platta and Tasna Nappes. (c) Geological map of Platta modified after Schaltegger et al., (2002). with sample locations. Cretaceous magmatic sills (red) have been magnified for clearance.

Supplementary material S2: Schematic section representing the lithologies and their stratigraphic position in the Platta nappe. Note that the shear-zone in mantle and the sulfide deposit are truncated by the detachment fault. Redrawn after Peters et al., (2008) and own fieldwork observations. 
Supplementary material S3: Locations and mineralogical assemblage of studied magmatic samples.

490 Coordinates grid is WGS84 UTM 32N, decimal degrees. Fds (Ab): feldspar (albite), Cal: calcite, Chl: chlorite, Cpx: clinopyroxene, Ep: epidote. Crosses indicate relative mineral proportions. Note that samples 13-03 and 13-04 are from the Tasna nappe.

Supplementary material S4: Analytical method

494

495

496

497

498

Major and trace elements were measured using the analytical method of Chauvel et al., (2011) at Laboratoire d'Hydrologie et de Géochimie de Strasbourg (LHyGeS, University of Strasbourg, France). For major elements, $\sim 50 \mathrm{mg}$ of sample powder was precisely weighted and dissolved in closed Savilex ${ }^{\circledR}$ beakers using a mixture of $0.3 \mathrm{~mL} \mathrm{HF} 24 \mathrm{~N}$ and $0.85 \mathrm{~mL} \mathrm{HNO}_{3} 14 \mathrm{~N}$ in a hot plate at $90^{\circ} \mathrm{C}$ for 5 days. $20 \mathrm{ml}$ of boric acid $\left(\mathrm{H}_{3} \mathrm{BO}_{3}\right.$

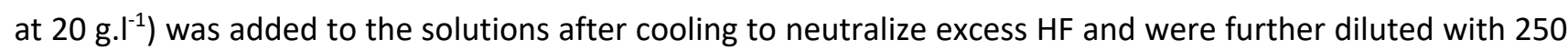
$\mathrm{ml}$ of Milli-Q ${ }^{\circledR}$ water. The solutions were then stored in a refrigerator for at least 2 days to ensure complete neutralization of $\mathrm{HF}$ by $\mathrm{H}_{3} \mathrm{BO}_{3}$ and analyzed within a week using an ICP-AES (Thermo Scientific ICAP 6500). For trace elements, $100 \mathrm{mg}$ of sample powder were dissolved in a $\mathrm{HF}-\mathrm{HClO}_{4}$ mixture $(5: 1)$ in closed teflon beaker on a hot plate at $140^{\circ} \mathrm{C}$ for 7 days. The mixture was then completely evaporated at $150^{\circ} \mathrm{C}$, and the residue was taken up in concentrated $\mathrm{HNO}_{3}$. After another complete evaporation, the residue is finally diluted in $40 \mathrm{~mL}$ of $\mathrm{HNO}_{3} 7 \mathrm{~N}$. The international standard PM-S (gabbro) was analysed repeatedly as unknown to ensure the validity of our measurements. Results show that PM-S concentrations are consistent with the preferred reference values from GeoREM (Jochum et al., 2008). Differences are less than $0.6 \%$ for $\mathrm{SiO}_{2}$ and less than $2 \%$ for all other major oxides except for $\mathrm{Na}_{2} \mathrm{O}, \mathrm{K}_{2} \mathrm{O}$ and $\mathrm{P}_{2} \mathrm{O}_{5}$ which are present in very low concentrations. In addition, sample 24-04 has been analyzed twice as a duplicate and results show no relevant differences in trace elements between the two aliquots. It is noticed that the anomalous composition of one sample (20-03), which is characterized by very low $\mathrm{SiO}_{2}$ (36.92 wt.\%), high CaO (15.33 wt.\%) and high LOI (9.33 wt.\%), is explained by the amount of calcite veins and is not used in the discussion. 
Supplementary material S5: (a) (La/Sm) $)_{N}$ vs. $(\mathrm{Sm} / \mathrm{Yb})_{N}$ of Alpine basalts compared to present-day MORBs (Gale

514 et al., 2013). Sample position reflects their shape of REE patterns, which depends on melting processes and/or

515 the source composition. Most of present-day MORBs (N-MORBs) are explained by moderate to high degrees

516 of partial melting (Gale et al., 2013) of a depleted mantle source in the spinel stability field (Workman and

517 Hart, 2005) as represented by the small graph in the lower left corner. In contrast, most Alpine basalts

518 (including basalts from the Platta and Tasna nappes) are characterized by high $(\mathrm{Sm} / \mathrm{Yb})_{N}$, suggesting the

519 involvement of garnet in the mantle source. Samples that plot in the upper right part of the graph (i.e. E-MORB)

520 can be related to low degrees of melting of a garnet depleted mantle source although they more likely derive

521 from the melting of an heterogenous, enriched source. N-star: N-MORB average $\pm 2 \sigma$ (grey area); E-star: E-

522 MORB average (Gale et al., 2013). PM: partial melting, sp: spinel, gt: garnet. (b) Nb/La vs. (Sm/Yb) of Alpine

523 basalts compared to present-day MORBs. The calculated aggregated non-modal fractional melts derived from

524 a spinel Iherzolite (in red) and a garnet Iherzolite (in green) are shown. The mantle source chemistry is the

525 DMM from Workman and Hart, 2005, and results using the enriched (E-) and depleted (D-)DMM are also shown

526 to not have a narrow vision of the heterogeneous geochemistry of the DMM. Numbers in italic indicate the

527 degree of partial melting. Partition coefficients are from Johnson et al., (1998), starting mineralogy and modes

528 are from Johnson et al., (1990). 


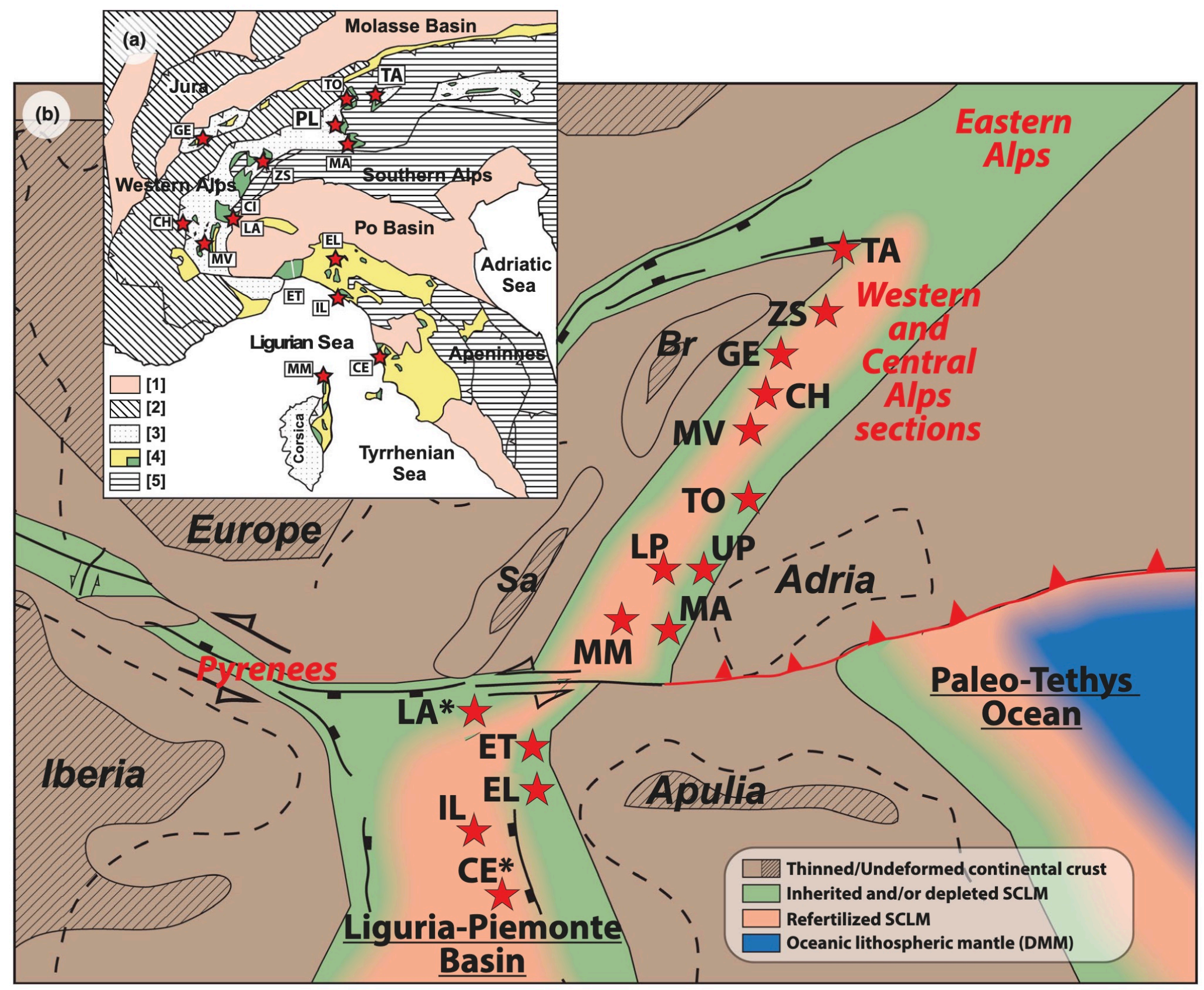



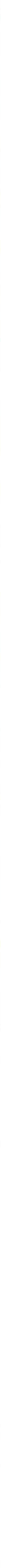
(a) Melt percolation

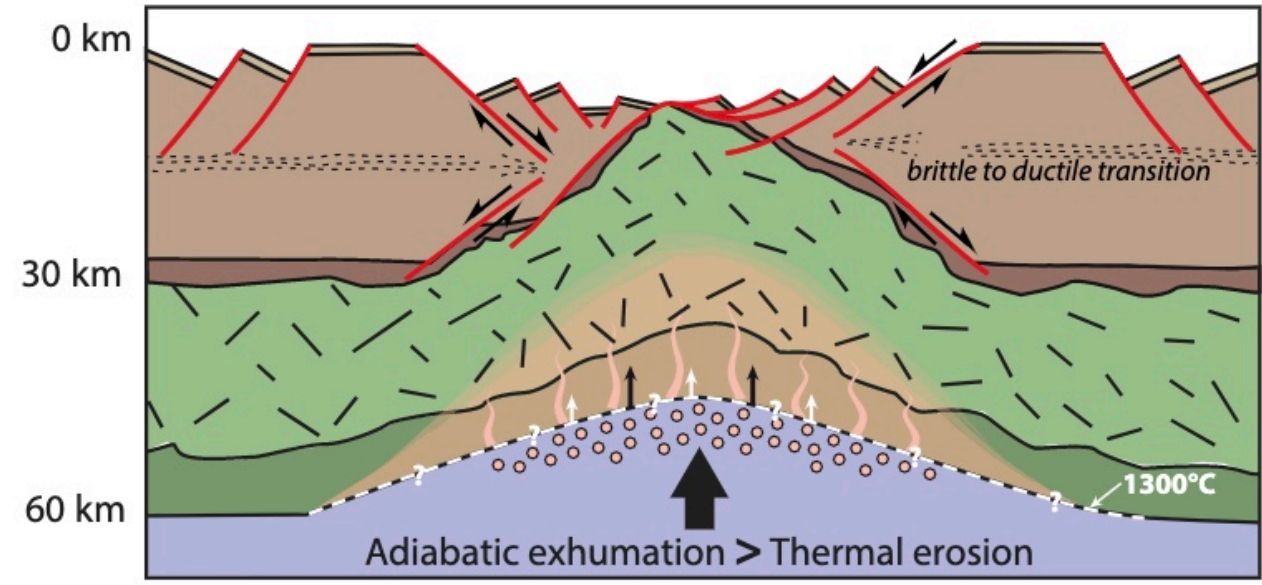

(b) OCT-basalts

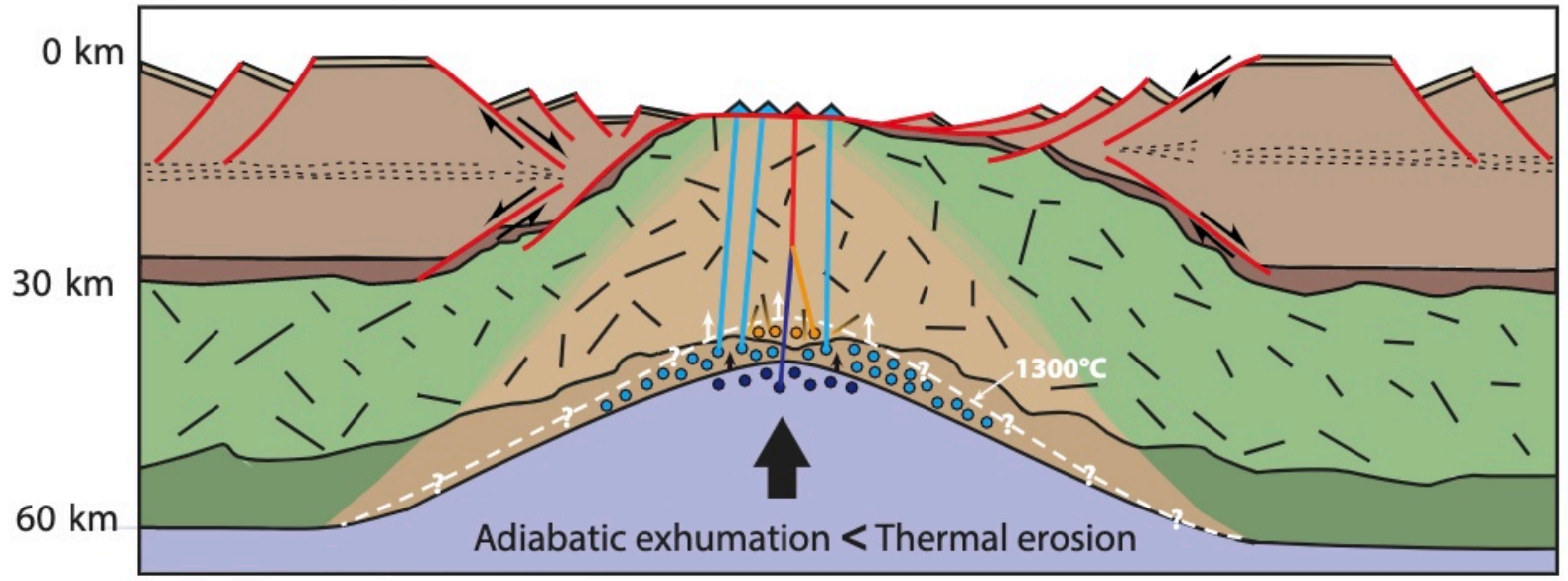

(c) MOR-basalts

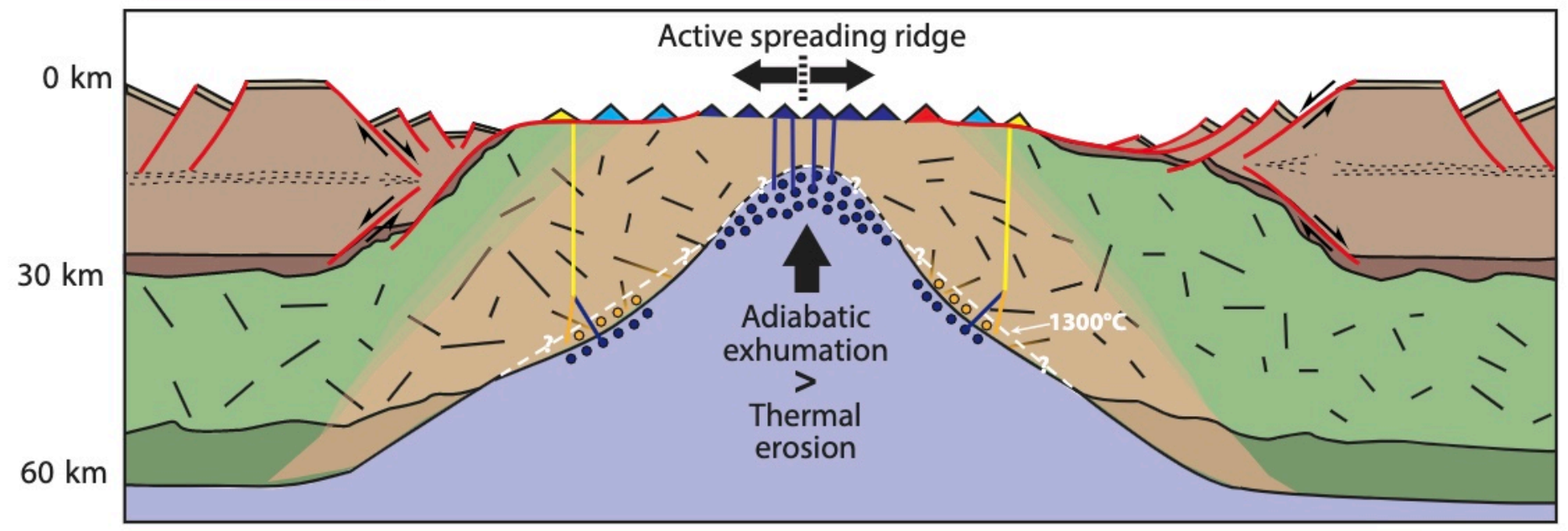

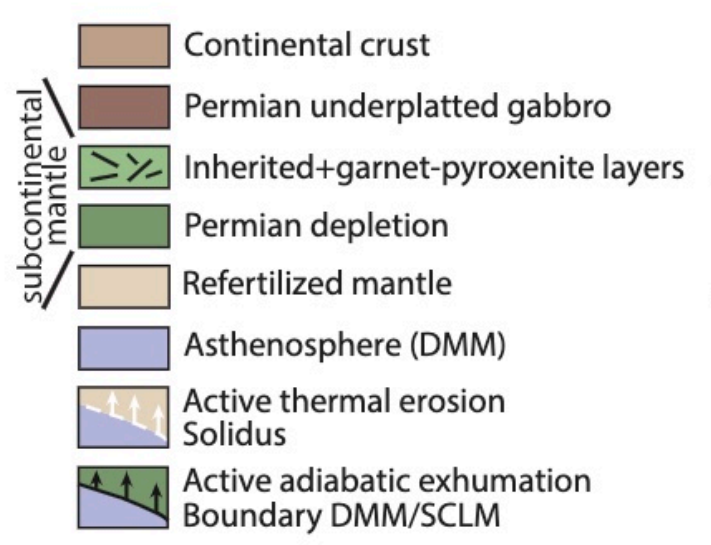

Refertilization process

Porous melt flow percolation

$\circ$ Partial melting of DMM

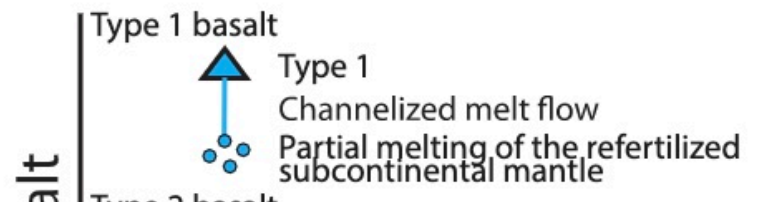

Type 2 basalt

$\frac{\mathfrak{0}}{\frac{1}{1}}$

MOR-basalt

$$
\begin{aligned}
& \text { Type } 2 \\
& \text { Mixing melt flow } \\
& \text { 0.0 Partial melting of the DMM } \\
& \text { and garnet-pyroxenite }
\end{aligned}
$$

Type 3 basalt

A Type 3

Mixing melt flow

$\therefore$ Partial melting of the DMM and garnet-pyroxenite

\footnotetext{
$\triangle$ MORB

Channelized melt flow

Partial melting of the DMM
} 

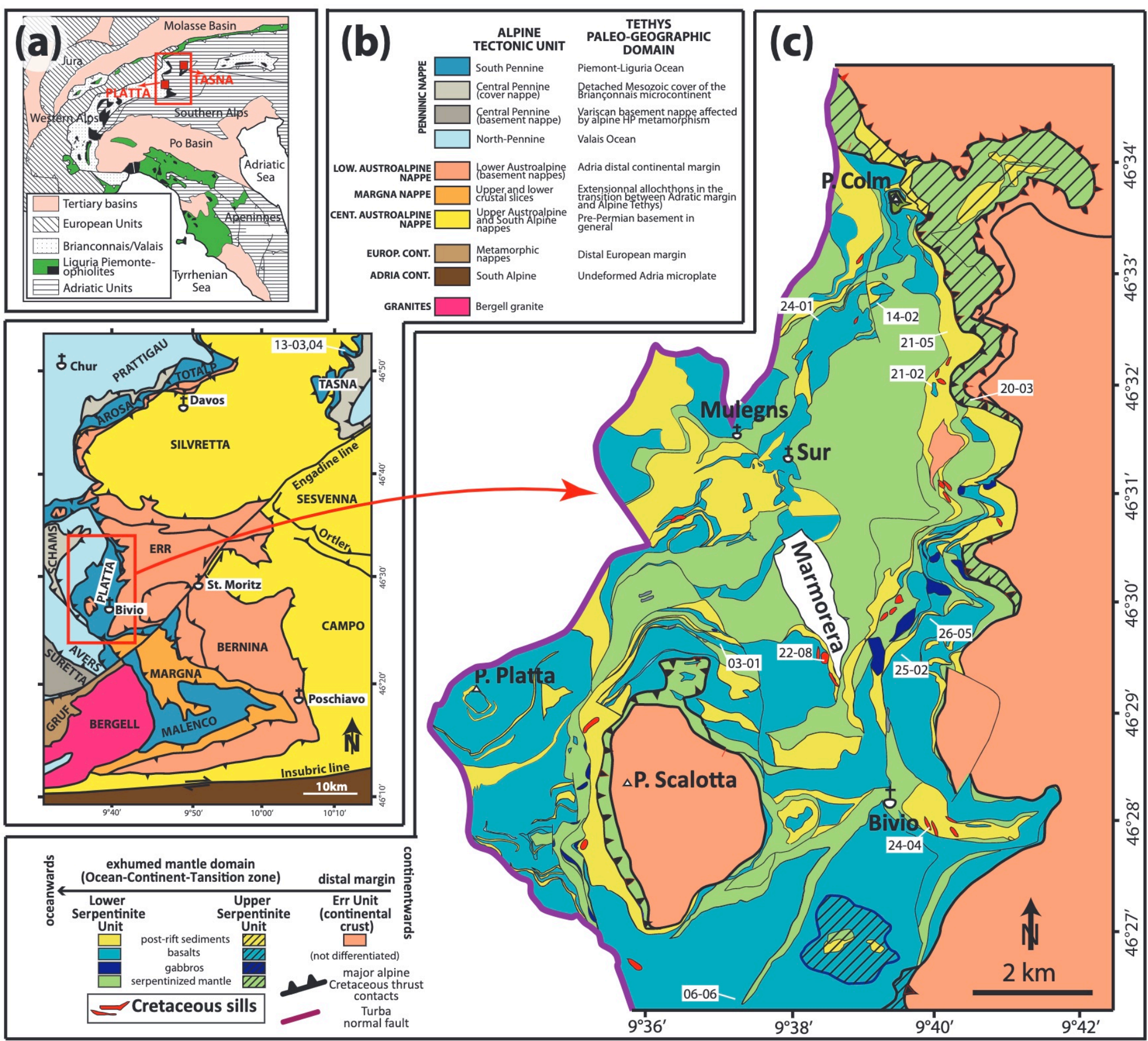


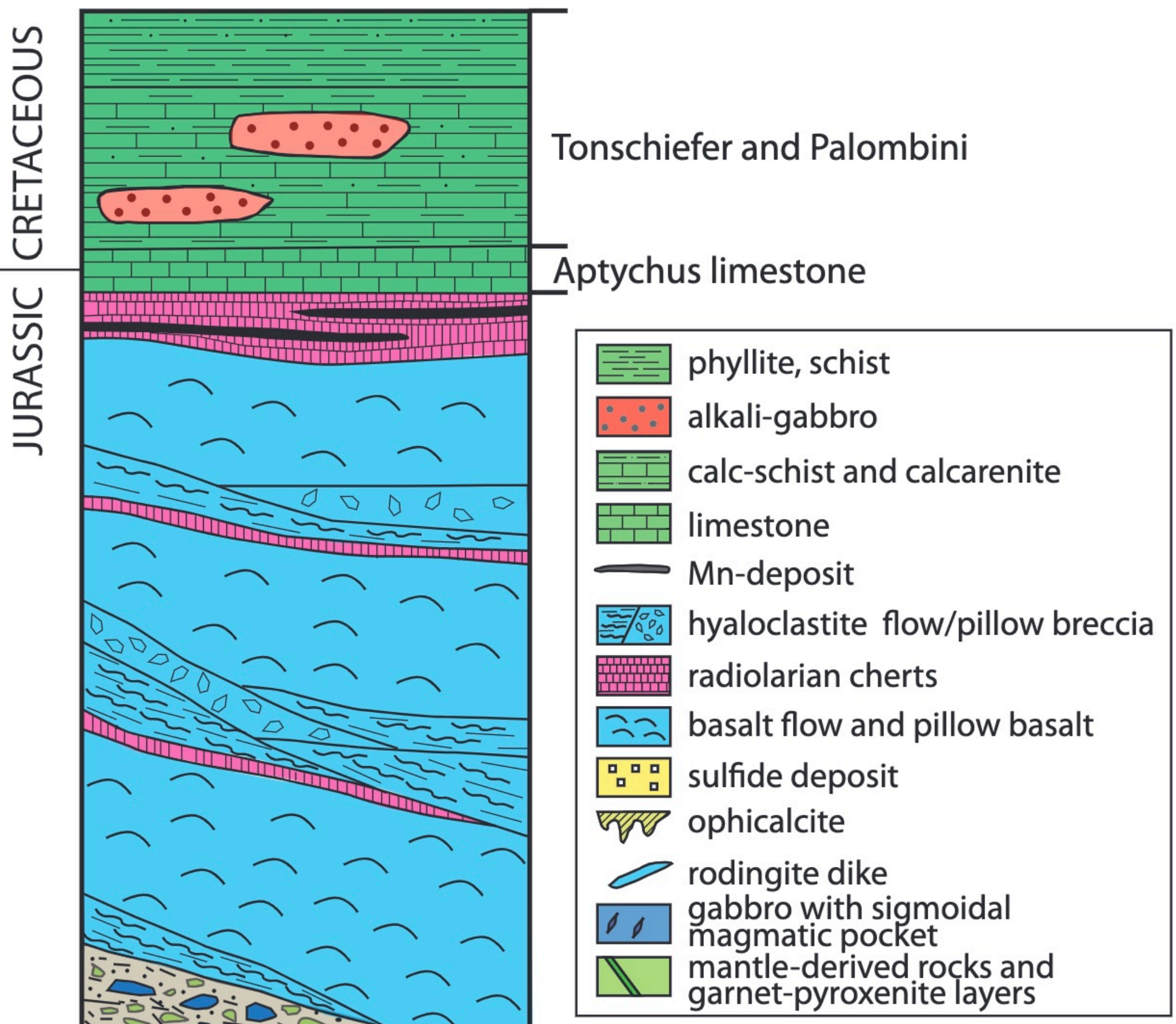

\section{Detachment fault}

(gouge, breccia with gabbro and serp. clasts)

Shear-zone (rodingitized basaltic dikes) 

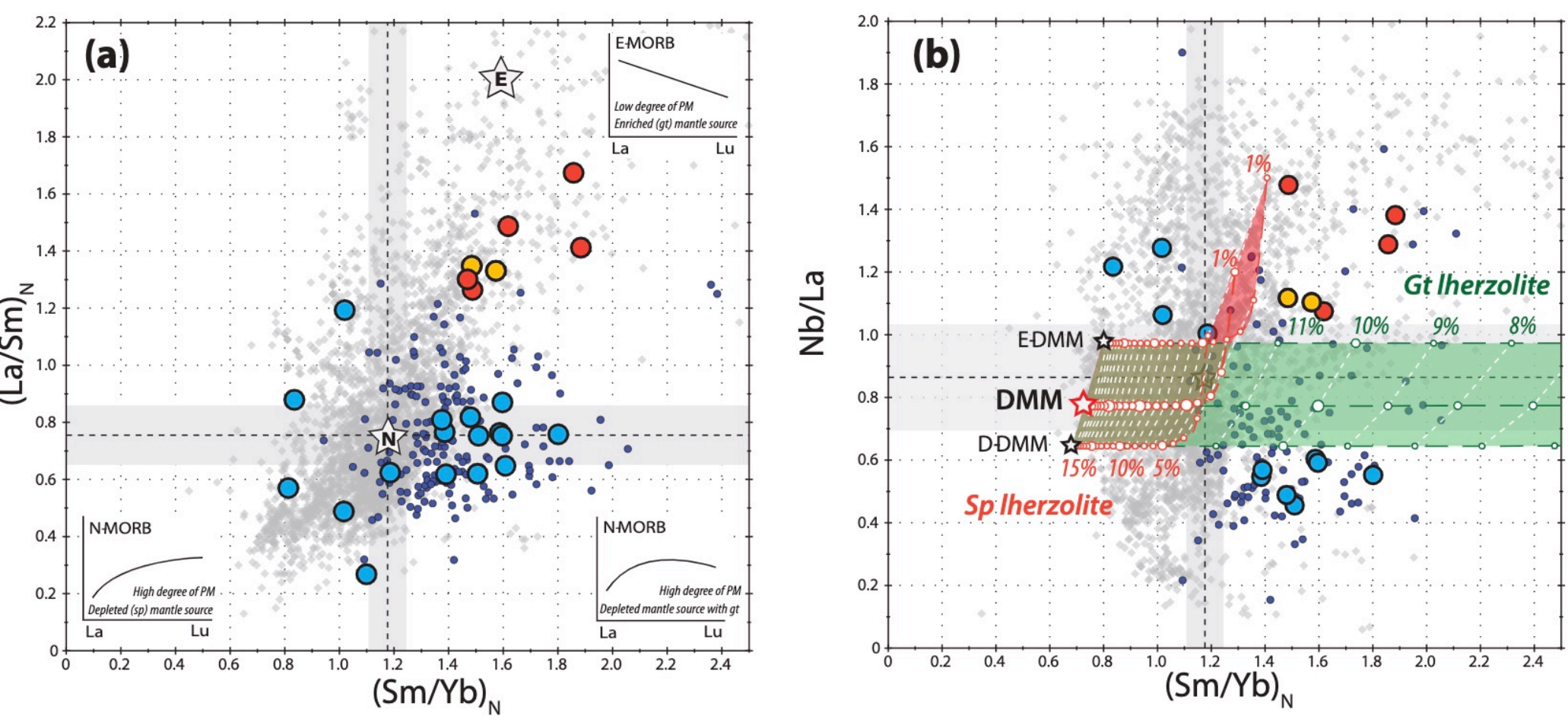